\title{
THE MISSING LINK: AFRICAN HISPANISM AT THE DAWN OF THE MILLENIUM
}

\author{
(c) M'Baré N'gom
}

The purpose of this work is to explore some thoughts and ideas about the African dimension of Hispanidad through literature. The specific object is the literary creation of Equatorial Guinea, the only subSaharan country with a literature of Spanish expression. This literature has not received much critical or theoretical attention in Africa, in Europe, or in America. In Spain, the former colonial power, this absence is also evident in universities and in secondary school curricula.

I will first contextualize my work by attempting to define the concept of Hispanidad from an African and bantú perspective. Hispanidad has been described as the community of Spanish speaking countries (and peoples) around the globe. According to this broad definition, Hispanidad should include countries and populations in Europe (Spain and Andorra), Hispanic America and North America (including Spanish speaking communities in the United States), parts of Asia (such as pockets of Spanish speakers in the Philippines), and in Africa (Equatorial Guinea and The Sahraoui Democratic Republic). Guinean scholar and writer Trinidad Morgades Besari (1987)writes:

La Hispanidad es un sentimiento; diría más es una filosofía, una vía de futuro, un quehacer común a todos los hispanohablantes. Es una herencia inagotable a la que siempre habremos de recurrir cuando nos falta el aliento espiritual para seguir hacia adelante, a pesar de los avatares de esta vida. Y si consideramos que el mundo en que vivimos hoy, tiene una necesidad vital de integrarse en grandes unidades políticas, económicas y culturales, porque la unión hace la fuerza, nosotros, los guineanos y el resto del mundo de la Hispanidad, comprenderemos por qué hemos de recurrir a la Hispanidad en busca de valores que nos lleven a una acción común, a fin de conseguir realizaciones prácticas y esperanzadoras para un mundo futuro mejor planificado y organizado (Africa 2000: 39-40)

Along the same lines, Guinean journalist, historian, and author Donato Ndongo-Bidyogo(1986), observes:

La Hispanidad de ahora mismo no es una propuesta de vuelta a las brumas de nuestra niñez, tiempo en que fuimos los apéndices de aquel "imperio" otoñal de selvas tropicales y montañas nevadas. La Hispanidad de ahora mismo es un engranaje a través del cual los países y pueblos de esta estirpe común potenciaremos nuestros 
valores específicos en el mundo, nos ayudaremos mutuamente a salir de las dificultades particulares y nos sabremos siempre unidos a través de la lengua, de la cultura y de ciertos valores humanísticos, sin que ninguno pueda sentirse desamparado por orfandad (Africa 2000:3).

Needless to say, this vision transcends simple cultural affinity and aim for stronger ties at political and economic levels. It is all the more important to note this, because unlike organizations like Francophonie, for the former French and Belgian colonies, and Commonwealth, for the former British colonies, Hispanidad is not an institutional organization, rather it draws upon Spanish language as a linguistic and cultural unifier. Despite its integration oriented perspective, African Hispanicism, has received very little attention within cultural studies. It is this academic, critical and theoretical invisibility that has led Guinean poet Ciriaco Bokesa Napo(1996) to point out that,

Las literaturas africanas todas se expresan en esos idiomas. Ahora bien, el carácter vinculante del idioma y cultura está más que estudiado desde el ángulo del inglés, del francés, y, en menos grado, del portugués. Pero, lo español, en tierras africanas y de plumas estrictamente africanas, queda en la memoria de una cita apenas esbozada (Prólogo).

The republic of Equatorial Guinea is located in the Gulf of Guinea, or Biafra, between Gabon, Cameroon, and Nigeria.

The singularity of Equatorial Guinea is a combination of two elements. First and foremost is its Bantu heritage, i. e. , its Negro African dimension, and secondly, its unique situation as the only country south of the Sahara desert to use Spanish both as an official language, and as a vehicle of transethnic and transnational cultural expression and transaction. Trinidad Morgades Besari (1987) writes:

En Guinea Ecuatorial conviven fundamentalmente dos culturas: una de entronque bantu y otra enraizada en la hispanidad. El humanismo guineano se nutre del ensamblamiento de estas dos culturas; en ellas está su fuerza y su futuro esperanzador. Los valores hispánicos y africanos confluyen para formar el nuevo hombre guineano (Africa 2000: 39).

Consequently, Guinean literature, like other African literary expressions written in transcontinental languages, is the expression of two literary traditions: European, i. e. , Spanish in this case, marked by the strict and rigid norms of scripture, and African, Bantu, i. e. , 
Ndowe, Fang, and Bubi to mention a few, characterized by the more flexible and pragmatic rules of orality. Fernando Lambert describes this as a phenomenon of textual friction, i. e. , a process through which the African text ended up incorporating the European text. In light of the above, I will describe this cultural experience as "literatura hispano-negroafricana" [Hispanic Negro-African Literature]. However, Donato Ndongo-Bidyogo(1986) prefers the appellation Hispanoafricana [Hispanic African], for he writes:

Guinea es un país a la vez hispánico y africano, y en esa identidad simbiótica radica su originalidad, su esencia y la garantía de su autonomía. Al fundirse los valores de la cultura adquirida, los hispánicos, con los valores de la cultura heredada, los bantúes -pues todos los pueblos que componen nuestro Estado pertenecen a la cultura bantú, lo cual no conviene que se olvide-, se operó en el espíritu del guineano una transformación importante, y a nuestro juicio (pues son esas, y no otras, nuestras señas de identidad, que se ha ido estructurando en una nueva cosmogonía (. . . . . . . Hay guineanos que escriben, que pintan, que esculpen; que trabajan, en definitiva, desde su perspectiva hispanoafricana, para dotar a su país de ese dinamismo sin el cual el progreso sería imposible (Africa 2000: 3).

In conceptualizing and contextualizing this project as Hispanic (Negro)African, my intention is, on the one hand, to distinguish it from North African Hispanism, or what is left of it, and on the other hand, to differentiate it, to a certain extent, from the Afro-Hispanic cultural experience of Latin America, including the Caribbean. In colonial Spanish Guinea, intellectual life and cultural activities were limited to the island of Fernando Póo, more specifically, to the city of Santa Isabel now called Malabo. The only publication of the time was $\mathrm{La}$ Guinea Española, published by the missionaries of the Inmaculada Corazón de María at the Seminary of Banapá. La Guinea Española can be considered as the craddle of African literature written in Spanish. The first issue appeared in 1903. In addition to articles on the progress of evangilization, on the state of the colony, and on agricultural productivity, La Guinea Española featured sections such as "Página literaria" and "De nuestra biblioteca africanista" mostly devoted to religious literature. But first and foremost, the journal, as the motto under the name read, was "defensor y promotor de los intereses de la colonia". Therefore, it was a platform for the dissemination of Spain's colonial ideology in that part of Africa. 
In its January 10, 1944 issue, La Guinea Española organized a literary contest, inviting what it described as "Plumas coloniales" to send submissions:

Con el presente número, organizamos un concurso artístico literario que, pensamos proseguir en anos sucesivos para estimular las muchas plumas coloniales que con prestigio y decoro pueden figurar al lado de otras firmas metropolitanas y que, no dudamos han de contribuir a divulgar y exponer aspectos y temas coloniales desconocidos o parcialmente enfocados [1].

Needless to say that there were no natives among those "plumas coloniales"; however, natives were invited to send submissions dealing only with folklore. Three years later, in 1947, La Guinea Española opened a new section, "Historias y Cuentos", specifically limited to Guineans:

"Esta nueva sección que hoy comenzamos, un exponente del pensamiento de nuestros indígenas recogido tradicionalmente en cuentos, historias, narraciones, refranes y cantos, contribuyendo de esta suerte aperpetuarlos y a divulgarlos. Además de nuestra labor personal y la colaboración de los misioneros, confiamos en los alumnos del Seminario, maestros, colegiales de la misión, de la Escuela Superior Indígena y catequistas de nuestras reducciones que nos enviarán el mayor número posible de "historias" sobre cualquier tema" [2].

This invitation was also restricted to a specific group of people: students of the missions and seminaries, and teachers, i. e. , a group of individuals who lived in a controlled and alienated space. In addition, this initiative was male-oriented and excluded women. This institutional policy of marginalization would have a detrimental effect on the emergence of a female body of literature in Equatorial Guinea. Though the response was massive, those early "works" were, in fact, a mere transcription and translation into Spanish of the oral literary corpus of the different ethnic groups of the colony including the Fang,the ndowe, or the bubi. Moreover, all the texts were identified by their ethnic origin such as "historieta pamue", "leyenda bubi", or "cuento ndowe". Without being aware of it, these Guineans were just following in the footsteps of such authors as Senegal's Birago Diop, (Contes et légendes d'Afrique noire,1938),Bénin's Maximilien Quenum, (Légendes africaines: Côte d'Ivoire, Soudan, Dahomey, 1946), and the Ivory Coast Bernard Dadie, (Légendes africaines, 1953). 
During this interaction at the textual level(collecting and transcribing, and translating), a new cultural product evolved, one which Mineke Schipper describes as "written orality", while Pius Zirimu prefers to call it "orature". Intermediaries started manipulating the traditional texts. They stopped transcribing and translating, and began incorporating, among other things, some elements pertaining to European literary tradition. Though the "new" texts still relied heavily on oral tradition, they nevertheless acquired a more personal touch and a more autonomous form as Donato Ndongo-Bidyogo (1984) points out:

"(. . ) Bien pronto, obtuvieron conciencia de la importancia de su misión, y poco a poco, de modo apenas perceptible, fueron transformando la pura transcripción, la traducción en formas de creación autónomas,si bien aún ligadas intimamente a las fuentes originales"(22).

Since the act of translating from a source text to a target text is in itself an act of manipulation, therefore this process was not just limited to the thematic and structural levels. In resorting to the traditional literary corpus of their respective ethnic groups for inspiration, the first generation of Guinean writers were pursuing a double objective. First, they intended to reclaim what Paulin Hountoundji calls their "Certificate of Humanity", by inserting an ethnological discourse in their texts through the repetitive description of their customs, rituals, traditions, and legends. Secondly, they sought to obliterate the subaltern and marginal structures in which Spanish colonial discourse had installed them by generating alternative objects of knowledge about themselves, their history, and their culture. This writing project is evident, for example, in the early works of Rafael María Nze's La gallina y la perdiz (1950), Constantino Ocháa's Biom y los hombres rudos, Esteban Bualo Bokamba's "Kon, el Blanco" (1961) y "Le va toco Buwe (Al fin vimos la luz)"(1962) ], Jose Esono's "El topé del leopardo", Francisco Obiang's "Meyen, Meyene", and Marcelo Asistencia Ndong Mba's "Mientras la tumba brama en su selvática canción"(1962) to mention but a few.

In 1953, Leoncio Evita Enoy published what was considered to be the first novel of Guinean literature: Cuando los combes luchaban(Novela de costumbres de la Guinea Española. The novel was, as Evita himself puts it, "una novela etnológica de las costumbres de la tribu combé en cuyo medio se desarrolla la acción novelesca en el país del Muni de una época precolonial" (Diálogos. . . 33). Published in Madrid by the Instituto de Estudios Africanos of the Consejo Superior de Investigaciones Científicas, an agency of the General Franco's regime, the novel was used as a powerful instrument of propaganda to show the positive results of the civilizing mission of Spain in sub- 
Saharan Africa. Since the colonial space was authoritarian, unidimensional, monolithic, and a repressive environment by nature, Evita was very aware that he needed to make his discourse "understandable and acceptable" to the dominant order. This writing strategy misled censors and Carlos Gonzalez Echegaray who wrote in the prologue:

No deja de ser curioso el hecho de que la novela está pensada y sentida "en blanco", y sólo cuando la acción se desarrolla entre indígenas, solamente, en parte, y como un espectador, el escritor se

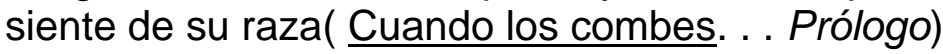

In the Preface to the Spanish edition of Rene Maran's Batuala. Verdadera novela de negros(1922), the first novel published by a black writer on colonial Africa in Africa, José Mas Laglera, one of the leading Spanish africanists of the time and translator of the novel, wrote:

"La novela no sólo era de negros, sino que estaba escrita por un individuo perteneciente a esta raza. El caso me pareció insólito. Yo no podía concebir que un negro del Congo tuviese aptitudes de escritor. Sabía que, educándoles en Europa, llegaban a ser buenos bailarines y que algunos hasta habían llegado a tocar la trompeta y el violín con verdadero arte; pero de esto a describir paisajes y estados de almas, había mucha distancia(. . . ). René Maran tiene de negro más que el color de la piel"(III).

José Mas Laglera would be echoed thirty years later, in 1953, by Carlos González Echegaray, another Africanist. In the prologue to Leoncio Evita's Cuando los combes luchaban, González Echegaray writes:

"Cuando Leoncio Evita me dió a leer su novela y me pidió que le hiciera un prólogo, no le di mi palabra de escribírselo hasta que no me convenciera de que se trataba de algo distinto de los relatos inconexos y absurdos que algunos "morenos" seudointelectuales escriben(... ). Pero mi sorpresa fue en aumento a medida que iba leyendo, al encontrarme con una obrita francamente aceptable, y que bien pudiera haber sido escrita por cualquier escritor novel nacido en nuestra patria"(Prólogo).

It is this perception and representation of Africans, Guineans in this case, that has led Evita to comment that, "La situación colonial que prevalecía cuando escribí mi novela, me dió un gran estímulo para seguir escribiendo y ampliar mis conocimientos. Personalmente, sentí gran satisfacción por abrir aquella pequeña brecha en el "dique" del 
monopolio de la discriminación intelectual" [3]. Ciriaco Bokesa Napo describes that period as "la época del temor al blanco cuando escribir suponía alabarle y quasi marginar cuando ridiculizar lo autóctono. Otras veces, se escoge lo nativo como noticia macabra para la metrópoli [4]. " Nearly a decade later, in 1962, Daniel Jones Mathama published Una lanza por el boabi. Mathama Jones' novel fervently celebrates the colonial situation, and it is strongly critical of the natives. It is part of what has been called literature of consent.

Between 1963 and 1968, during the heyday of the nationalist struggle for independence, a few Guineans still published in journals such as $\mathrm{La}$ Guinea Española, Poto-Poto, and Bantú. It is also during this period that a new literary genre appeared on the cultural scene: poetry. Guinea and Africa are the major themes of these poets as evidenced by Juan Chema Mijero's "El león de Africa" (1964), and Francisco Zamora Segorbe's "Lamento sobre Annobón, belleza y soledad" (1967), and Ciriaco Bokesa's "Isla verde" (1968), to mention but a few.

Guinean literature has followed a different path from African literature in French and English, a path also quite different for that of the special cases of Portuguese and South African literature. First, guinean literature was late to arrive to the African literary scene, and second,in Spanish Guinea, literature did not develop side by side with the nationalist movement for freedom from colonial rule. Neither the Négritude nor the African Personality movements had the same echo and impact in Guinea that they had in other parts of the continent. The Spanish colony was isolated. Linguistically, Guinea was in a predominantly francophone area, and geopolitically, Spain's policy of containment, along with tight censorship, kept Guinea cut off from the rest of the world. Translations of texts by other African authors or intellectuals were not allowed in the colony. Consequently, Guinean intellectuals missed two major cultural events closely associated with the nationalist movement for freedom such as "Le Premier Congrès des Ecrivains et Artistes Noirs" held at The Sorbonne in Paris in 1956, and the second Congrès held in Rome in 1959. My provisional conclusion is that there was not an anti-colonialist literature, i. e. , a committed literature in the sense it was defined by Léopold Sédar Senghor at the Congress of Negro Writers at the Sorbonne in Paris in 1956("La littérature africaine est une littérature engagée"). Guinean journalist and writer Donato Ndongo-Bidyogo(1984) corroborates this view:

" Los escritores guineanos, como el resto de los africanos, están poseídos por su realidad circundante, aunque en la primera etapa 
casi se apuntaba en una sola dirección, y, en rigor, no se puede hablar de una literatura anticolonialista en Guinea Ecuatorial(. . . ).

por más que en algunas obras se describa algún exceso(28).

A few years later, when Guinean intellectuals came in direct and open contact with the remnants of the Negritude movement, some of them, like Donato Ndongo-Bidyogo, expressed apprehension because they felt Négritude no longer addressed issues relevant to the new postindependent reality. In his poem Cántico (1984), Donato NdongoBidyogo writes:

Yo quiero ser poeta

para cantar a Africa

Yo no quiero ser poeta

para glosar lo negro

Yo no quiero ser poeta así(92)

A few years later, Donato Ndongo would further distance himself from the Négritude movement:

(... ) sencillamente no había en el alma del guineano esa necesidad de un resurgimiento cultural al modo de la explosión de la Négritude, que se pondría los cimientos del nacionalismo cultural y político en el Africa subsahariana [5].

Here lies what seems to be a contradiction because Las tinieblas de tu memoria negra, the title of Donato Ndongo's first novel, comes from a poem by Leopold Sédar Senghor, one of the founding fathers of the Negritude movement.

On October 12, 1968, Equatorial Guinea gained its independence from Spain, nearly ten years after most sub-Saharan countries. The independence of most sub-Saharan possessions in the early 1960s, and the ensuing establishment of new institutional structures, had stimulated the emergence of a new political and cultural discourse described as National Project. The African Post-colonial reality had become the site for the emergence of national literatures and of what has been described as post-colonial discourses.

In March 1969,less than five months after his election to the Presidency, Francisco Macías Nguema denounced a coup attempt, 
declared a state of emergency, suspended the constitution, abolished political and social debate by banning all political parties, instituted a one-party rule, appointed himself Commander-in-Chief of the Armed Forces, and proclaimed himself President for life. Macías embraced the post-colonial African discourse of the time, known as African Authenticity, that Swiss historian Max Liniger-Goumaz described, in some cases as afro-fascism. Liniger-Goumaz called the Guinean version Nguemismo. Originally, the African discourse of authenticity as a nationalist discourse stood as a critique and alternative to Western hegemony. Unfortunately, it deviated from its original purpose and took a very demagogic course. In some countries it became the instrument of neo-colonialism, or turned into a dictatorship in others. Eventually it only benefited the ruling minority and failed to achieve political and economic independence. In the case of Equatorial Guinea, the colonial force was replaced with a new ethnicbased and ultimately exploitative force. Instead of liberation after decolonization, the new nation replicated the old colonial system of oppression and structures. President Francisco Macías Nguema established an ethnic dictatorship supported by the Fang-Esangui, his ethnic group also known as the Clan of Mongomo, Nguema's home province. Throughout his rule(1969-1979), Macías dealt brutally with opponents, civilians and militarymen who were not members of his clan. Nguemismo, as an ethnic hegemonic discourse, was manipulated and instrumentalized as a mobilizing force that symbolized "national unity" against re-colonization and neocolonialism. It sought to institutionalize itself in order to achieve hegemony and legitimation through violent practices. As a new postindependent nationalist discourse, Nguemismo also engaged in the task of rewriting the National History(Traditional and Contemporary) by falsifying it. As part of that discourse Macias Nguema declared himself:

- Gran Maestro de educación, ciencia, cultura de la república de Guinea Ecuatorial.

- Unico líder y héroe nacional

- Padre de la revolución y fundador del estado guineano

- Responsable supremo de los destinos históricos de nuestra nación

- Primer nombre sagrado y revolucionario de Guinea Ecuatorial

- Padre de todos los niños revolucionarios 
- Dios creó a Guinea Ecuatorial gracias a Macías, y sin Macías no hay Guinea" [6].

The goal of Nguemismo was to achieve total control of the public and economic spaces, and to render the rest of the social actors invisible by stripping them of their political culture. Guinea became a monoethnic state. In other words, the nguemismo "fanguicized" the Guinean post-colonial reality by establishing what Ngugi Wa Thiong'o calls the "Culture of Silence and Fear". The borders of the country were closed and freedom of movement of the citizenry was restricted. Guinea became "una gran jaula" [a big cage],i. e. , a huge concentration camp. This is how the narrator in El párroco de Niefang(1996) by Joaquín Mbomio Bacheng, describes that space:

"Salir con una barca a alta mar era considerado por el régimen de Macias como un acto de subversión que atentaba contra la seguridad del Estado. Por eso se mandó destruir todas las embarcaciones desde Mbonda hasta Río Campo y desde Cuche hasta Corisco. Nada podía navegar. Se prohibía a toda la población del Litoral el acceso a su propio espacio marítimo"(37).

Throughout the Nguemismo, books and other publications were banned, private correspondence was examined, and foreign press was prohibited. Donato Ndongo-Bidyogo (1990)dubs that period the "años del silencio":

(... ) no hubo ninguna manifestación literaria dentro de Guinea Ecuatorial, por la sencilla razón de que se perseguía a todo el mundo, fundamentalmente a aquellos que pudiéramos llamar intelectuales, y el simple hecho de hablar español era castigado con la cárcel. No digamos escribir: muchos guineanos murieron porque en cualquier registro domiciliario se les encontró apuntes en español. . . De modo que las únicas manifestaciones literarias de Guinea Ecuatorial durante aquel período se produjeron en el exilio" [7].

Printed material became a lethal weapon that played and was used against those who generated it: writers. Exile and silence became part of the post-independent Guinean reality. In the meantime, thousands of kilometers away in Spain, the discourse of resistance began to take shape. But it was a semi-clandestine and marginal discursive practice. On January 30, 1971, the Spanish government declared Equatorial Guinea "Materia reservada", and a total blackout was imposed on all news about Equatorial Guinea. Organized opposition to Macias regime was either restricted or in some cases, prohibited. This regulation stayed in effect until August 14, 1974. Produced in these precarious conditions, the discourse of the Guinean diaspora became 
a subculture which was disseminated through an underground and marginal circuit. It failed to reach the Guinean diaspora in Spain as well as the Spanish public. Nevertheless, that marginality was instrumentalized into a site of resistance.

This is the context within which we must place the anonymous poem El cinco de marzo which appeared in El Molifugue informa (7 septembre 1977), a bulletin published by one of the several organizations of the Guinean diaspora. The poem commemorates the violent appropriation of the Guinean reality by the nguemismo:

Cual primer llanto al nacer

las primeras lágrimas por mi tierra

EL CINCO DE MARZO

Las primeras muertes injustas,

el aborto de mi alegría,

EL CINCO DE MARZO

El desprecio por mi pueblo

y un dictador sanguinario

los crímenes y horrores,

EL CINCO DE MARZO

Los huérfanos de una patria

murió la ley y la justicia

el hombre perdió valor,

EL CINCO DE MARZO [8].

Guinean literature in exile relied mainly on poetry as a discursive platform of resistance, and revolved around two main themes: nostalgia that some of these writers described as "orfandad de tierra", and the traumatic experience of displacement. The theme of "orfandad de tierra" was characterized by nostalgic evocation of Equatorial Guinea as a remote and prohibited space; however, most of the poems idealize the country through vivid descriptions of its vegetation, 
beaches, rivers, and climate, i. e. , a geographical space that the displaced Guinean could easily identify. This can be found in Juan Balboa Boneke's Nostalgia Rebolana (1987):

Con la seca y la lluviosa,

con la fresca brisa matutina

Quiero viajar

para bañarme en tus raíces

y llenar de amor y hermandad tu entorno

Rebola(29).

Pedro Cristino Bueriberi Bokesa's Nostalgia de mi tierra(1984) :

Tierra mía, tierra mía!

Qué lejos estás de mí!

Mis ojos, suaves, anhelan

fieles tu verde verdí.

Los pájaros ya no cantan

Ya no se oye su clarín(56).

The second thematic area of this counterdiscourse explores exile not only as an experience of dislocation and fragmentation, but also as a process of cultural, political, linguistic, and economic deterritorialization. Poet and novelist Juan Balboa Boneke expressed the anguish of not belonging in ¿Dónde estás Guinea?, a book difficult to categorize because it contains poetry and prose:

"¿Quién soy yo? Se me ha arrancado de lo que era mi realidad, mi existencia, mi cultura (. . . ). Ni soy de aquí, ni soy de allá. Y cuando me descubro a mí mismo resulta que para mis hermanos (mi pueblo), soy un extraño. Sigo sintiéndome extraño en esta sociedad porque no acabo de sentirme comprendido, porque no acabo de comprender(Boneke 1982: 11). "

This sentiment is echoed by Francisco Zamora Loboch in Prisionero 
de la Gran Vía(1984):

Si supieras

que tengo la garganta enmohecida

porque no puedo salirme a las plazas

y ensayar mis gritos de guerra.

Que no puedo pasearme por las grandes vías,

el torso desnudo, desafiando al invierno

y enseñando mis tatuajes,

a los niños de esta ciudad(131)

This discourse reflects and denunces the violent and traumatic nature of Nguemismo which engaged in a process of systematic degradation and destruction of the Guinean body. In Epitafio(1984), one of his rare poems Donato Ndongo-Bidyogo writes:

Un tiro certero. . .

Ya nada,

Nada más

Que un cadáver

Muerto. Tierra

Fue un hombre(92).

And Anacleto Oló Mibuy's A un joven fusilado en Santa Isabel (1984):

Voy con esta luz de rimas

dejando flores estériles

en las burbujas de sangre,

y poniendo, piadoso 
en cada carne de tu cuerpo destrozado

las letras muertas de tu libertad(116).

In some cases, the discourse of the Guinean diaspora used an aggressive language calling for the elimination of the despot as in

Francisco Zamora's Vamos a matar al tirano(1984):

Madre:

Dáme esa vieja lanza

Que usó el padre

Y el padre del padre

Tráeme mi arco nuevo

Y el carcaj repleto de flechas

Que parto a matar al tirano

Mira mis ojos

Observa mi descripción

Pertenezco a un pueblo de revueltas

Observa mi hechura

de escaramuzas y levantamientos

Mi pulso no temblará(130).

It also incited insurrection as in Anacleto Oló Mibuy's La voz de los oprimidos (1984):

Mis poesías serán leídas un día debajo de mis árboles,

sin techos ni barnices de aire.

Muertos y vivos de corazón arañado de cualquier negra injusticia, mis poesías llamarán a la resurrección con la voz de los que no la tuvieron 
con la voz de los oprimidos(118).

There were also a few texts in prose. But for Nueva narrativa guineana, a collection of four short stories published, "con el fin de recaudar fondos para uno de los movimientos políticos de resistencia antimaciísta", according to Donato Ndongo-Bidyogo, most of the texts of this period were essays. Nueva narrativa. . . includes four short stories: Francisco Abeso's La travesía, Francisco Zamora's Bea, Donato Ndongo's El sueño, and Maplal Loboch's La última carta del Padre Fulgencio Abad. The other non-literary works include: Donato Ndongo Bidyogo's Historia y tragedia de Guinea Ecuatorial (1977), Juan Balboa Boneke's Donde estás Guinea(1978), and Eugenio Nkogo Ondo's La condición humana(1985). Raquel Ilonbe's Ceiba(1978) is the only text by a woman published during that period. Born Raquel del Pozo Epita from a Spanish father and a Guinean mother, she was taken to Spain when she was one year old, and lived there most of her life. Her experience of Guinea and the Guinean reality is quite limited. She is the first female author of Guinean literature.

On August 3, 1979, Francisco Macías regime was overthrown by a military coup described as "el golpe de libertad" led by his own nephew, Colonel Teodoro Obiang Nguema. It was a time of hope. Juan Balboa Boneke(1987) celebrated what he thought would be the dawn of a new era with a poem entitled "Tres de agosto 1979":

Y florecieron las sonrisas,

y la brisa de esperanza

que refrescó los hogares

camino de un futuro

triunfal aún por imaginar(48)

During the 1980s while "los espíritus se estaban serenando", as Donato Ndongo-Bidyoyo then put it, Equatorial Guinea engaged in a process of reconstructing and redefining a viable and inclusive national project. On June 6, 1982, during an award ceremony for national and international artists and intellectuals held at the Estadio de la Paz in Malabo, the President, Colonel Teodoro Obiang Nguema stated that:

La cultura debe ser considerada en mi Gobierno como prioridad absoluta, ya que sin ella el pueblo de Guinea Ecuatorial no podría 
asumir positivamente el proceso de la Reconstrucción y Reconciliación Nacional [9].

Whether by coincidence or not, there was a spectacular upsurge of cultural activities, a real cultural renaissance.

A two-tier and more or less simultaneous process took place in two different and distant locations: Equatorial Guinea and Spain. The first cycle originated in Spain, and coincided with the new democratic process after General Franco's death. The Guinean diaspora living in the Peninsula enjoyed more freedom of movement and expression. Within this context that the first writings of the Guinean diaspora began to appear in the early 1980s. One such texts was Raquel llonbé's Leyendas guineanas(1981), a collection of traditional stories from different Guinean ethnic groups collected by the author throughout Equatorial Guinea "in search of her roots" as she put it. Raquel llonbe dedicated Leyendas guineanas " a todos los niños guineanos y a los de los cinco continentes". These words seemed to indicate a very promising future not only in the field of children's literature in Equatorial Guinea, but also in the recovery of oral tradition. Then followed two books of poetry both by Juan Balboa Boneke: O'Boriba(El exiliado)(1982) y Susurros y Pensamientos comentados: Desde mi vidriera(1983). These reflect on his decadelong exile. In 1984, Donato Ndongo-Bidyogo published Antología de la literatura guineana, the first comprehensive attempt to give a textual overview of Guinean literature from the colonial period to what French journalist Gilbert Wassermann calls "la première indépendance" ["the first independence"]. In 1985, the Ediciones de la UNED(Universidad Nacional de Educacion a Distancia) in Madrid published Ekomo by María Nsue Angüe. Ekomo is the first novel by a female writer in Guinean literature. The novel gives a fresh, genuine, profound, and different perspective on the condition of women among the Fang ethnic group. It is also the first attempt to give alternative images and representations of fang women by a fang woman. In 1987, Donato Ndongo-Bidyogo published his first novel: Las tinieblas de tu memoria negra which is the first volume of a trilogy whose second part, LoS poderes de la tempestad, appeared ten years later in 1997. While in Las tinieblas Donato Ndongo explores the colonial situation through the innocent eyes of a child growing up in an alienated space, in Los poderes. . . he examines the Guinean reality under the nguemismo which he calls "los años de desgobierno de Macías". Though both texts use autobiography as a narrative platform, Donato Ndongo denies he does so, for, he says it is,

un ejercicio catártico, una doble interiorización, tendente a exorcizar los "demonios" acumulados a lo largo de la existencia del pueblo 
guineano: las supersticiones, el colonialismo, el racismo inherente a la acción colonizadora y el que provoca, como reacción, en los colonizados(. . . ). En el caso concreto de Las tinieblas. .. , no se puede hablar de una autobiografía en su sentido estricto. En todo caso, sería la "autobiografía" de la sociedad guineana actual. . . [10].

The second center of the cultural renaissance was the Centro Cultural Hispano-Guineano in Malabo. Founded in 1982, the mission of the Centro Cultural was " la activación de la vida cultural, artística, folklórica, educativa de nuestro país", i. e. , to promote and disseminate Guinean and hispanic culture in Equatorial Guinea and abroad. In addition to establishing an editing and publishing arm, Ediciones del Centro Cultural Hispano-Guineano, the Centro Cultural also houses the largest library of the country, and publishes two journals: Africa 2000 and El Patio. Ediciones del Centro Cultural has established several publication series called "colección" in order to accommodate the different intellectual interests that emerged in the wake of its ever growing activities. The "Colección Poesía" has released several anthologies and poetry books including Juan Balboa Boneke's Sueños en mi selva(1987); Ciriaco Bokesa Napo's Voces de espumas (1987), Juan-Tomás Avila Laurel's Poemas (1994), Jerónimo Rope Bomabá's Album poético (1995), and more recently JuanTomás Avila Laurel's Historia íntima de la humanidad(1999); the "Colección Relatos" started in 1994, includes to date Maximiliano Ncogo's Adjá-Adjá y otros relatos (1994). The "Colección Narrativa" is the largest one so far, but I will just mention two titles, the first and the seventh. Iñigo de Aranzadi's El tambor opens this series. An Africanist and former colonial officer in Spanish Guinea, Arazandi collected this story by means of interviews with a Fang story teller in 1959. What makes Aranzadi's text different and interesting is that it is a bilingual edition: there is a Spanish translation, a phonetic version, and the original version in Fang. The book contains a lot of colorful illustrations that makes it attractive to children. Arazandi touches a very critical point in African literature: language, but whose language and which one? The seventh text in this collection "narrativa" is Joaquín Mbomio's El párroco de Niefang (1996). The "Colección Ensayos" is more diverse, for it accommodates different disciplines. And finally, the "Colección Litertura popular" the last born, whose first text is Rusia se va a Asamse(1998) by Juan-Tomás Avila Laurel.

Africa 2000 and El Patio have acquainted the Guinean public with writers whose works appeared while they were in exile. Africa 2000 and El Patio have also served as a launching pad for young and novice writers from the mid-1980s onward. 
The Centro Cultural sponsored two very important cultural events in the 1980s: the "I Congreso Internacional Hispánico-Africano" held in Bata (Continental Guinea), June 4 -8, 1984 with the participation of 80 delegates representing 18 countries, as well as international and religious organizations, and also the "Coloquio Internacional de Hispanistas" held in the capital, Malabo, Febrero 16-23, 1985 with representatives from 10 countries including Germany, Poland, Spain, and from Africa, Senegal, Cameroon, Gabon to mention but a few.

Finally, I would like to point out that neither the Spanish cycle nor that of the Centro Cultural have concluded yet. During a short period in the 1980s, the government of Teodoro Obiang tried to control the production of cultural discourse in Guinea by creating the shortlived ediciones Guinea which edited a few books before closing. I will only mention two titles. The first one is a book by President Teodoro Obiang himself Guinea Ecuatorial, país joven, a long essay on his program of national reconciliation and reconstruction; the other is Juan Balboa Boneke's first and only novel, El reencuentro. El retorno del exiliado(1985) in which the author reflects on the process of national reconciliation. Most Guinean intellectuals opted to turn their back to this platform.

In the 1990s, Equato-Guinean literature kept growing despite setbacks in the political life of the country. Some authors started exploring alternative and new discursive platforms such as drama/theater. Though there are very few writers who have ventured into this field, those who did have realized that theater's is far-reaching capacity makes it an effective means to explore the Guinean postindependence. Trinidad Morgades Besari's Antigona, Juan-Tomas Avila Laurel's Los hombres domésticos, and Pancracio Etogo Mitogo's El hombre y la costumbre are part of this burgeoning literary trend. Closely related to the former process, is the emergence of a new generation of writers. Most of them were children during Nguemismo, and unlike the previous generation, they started their literary career in Equatorial Guinea. They form what poet Anacleto Oló Mibuy describes as "nueva narrativa nacional" or "nuevo costumbrismo nacional" in prose. They use a new style and focus on the immediate reality of the "second independence", and to paraphrase Gilbert Wasserman with its contradictions made of repression, lack of freedom, hardships, broken promises, corruption, and a country immersed in a deep economic crisis.

This difficult and precarious economic, political, and cultural environment drove the few Guinean intellectuals and professionals like poet Juan Balboa Boneke and Donato Ndongo-Bidyogo back into exile. They had returned home after the "Golpe de libertad" in order to 
participate in the process of national reconciliation and reconstruction, but had to flee to save their lives. Closer to us in Vermont, another Guinean writer, poet and playwright Gerardo Behori Sipi, not only had to leave hastily, but to leave behind most of his writings. In a letter he sent me shortly after he fled the country for his second exile, Juan Balboa Boneke wrote:

Por aquí las cosas no van bien. En el proceso de democratización de mi país, hemos fracasado. Las elecciones multipartidistas del 21 de noviembre(1997) constituyeron un gran fraude por parte del Gobierno. Hubo y sigue habiendo represión, torturas, y muertes (son 11 muertos ya). Salí del Gobierno y abandoné la política [11].

For those who had no other choice but to remain in the country, two attitudes can be pointed out. There are those like poet Ciriaco Bokesa Napo who chose self-censorship and silence as a strategy of resistance and denunciation; and there are others, like Maximiliano Ncogo in Adjá-Adjá y otros relatos, who use humourous situations to expose the ills of what Juan Balboa Boneke calls the "obiangnguemismo". In closing, let me quote Donato NdongoBidyogo(1998) :

La literatura hispanoafricana(. . . ) está llamada a ser el tercer vértice del eje afro-hispano-americano, que configura hoy la geografía lingüística de nuestro idioma común. A poco que se estimule, cumplirá su papel en la tarea de revitalizar la lengua y cultura en español, que ya no pueden ser comprendidas si las desgajáramos del aporte negro, como demuestran las obras de Nicolás Guillén, Manuel Zapata Olivella, Adalberto Ortiz o Nicomedes Santacruz (Mundo Negro:9).

Morgan State University

Baltimore, Maryland

\section{Notes}

1). La Guinea Española, núm. 1165, 10 de enero de 1944.

2). La Guinea Española, núm. 1236, 10 de enero de 1947: 13.

3). "Entrevista a Leoncio Evita," Diálogos con Guinea, 33.

4). Ciriaco Bokesa Napo. Diálogos con Guinea, 104. 
5). Estudio introductorio de Cuando los combes luchaban( $2^{\underline{a}}$ edición). Malabo: Ediciones del CCHG, 1996.

6). Donato Ndongo-Bidyogo. Historia y tragedia de Guinea Ecuatorial. Madrid: Editorial Cambio16, 1977: 213-14.

7). Donato Ndongo-Bidyogo. Letter to M'Bare N'Gom from Malabo, Equatorial Guinea dated on October 22, 1990.

8). "Cinco de marzo", El Molifugue informa, núm. 7 (Sept 1977):

Sección Recuerdo y poesía.

9). Teodoro Obiang quoted by Leandro Mbomio, "Africa 2000 en las ondas," Africa 2000(1990): 11.

10). "Entrevista a Donato Ndongo-Bidyogo," Diálogos con Guinea, 7374.Guinea, 73-74.

11). Juan Balboa Boneke. Letter to M'Bare N'Gom from Paterna, Valencia dated on February 12, 1994.

\section{Works cited}

Balboa Boneke, Juan. Letter to M'Bare N'Gom from Paterna, Valencia, dated February, 1994.

. Sueños en mi selva. Antología poética. Malabo: Ediciones del Centro Cultural Hispano-Guineano, 1987.

. Juan Balboa Boneke, ¿¿Dónde estás Guinea?, Palma de Mallorca, Agrupación Hispana de Escritores, 1982.

Bokesa Napo, Ciriaco. "Prólogo" de Diálogos con Guinea. Panorama de la literatura guineoecuatoriana de expresión castellana a través de sus protagonistas. (M'Bare N'Gom). Madrid: Ediciones Labrys 54, 1996.

Evita Enoy, Leoncio. Cuando los combes luchaban. Novela de costumbres de la Guinea Española. Madrid: CSIC, 1953.

La Guinea Española, número 1165, 10 de enero de 1944.

, año XLII, número 1236, 10 de enero de 1947: 13-15. 
Mas Laglera, José. Prólogo. Renato Maran. Batuala. Verdadera novela de negros. Madrid: V. H. Sanz Calleja editores e impresores, 1922.

Mbomio, Leandro. "Africa 2000 en las ondas," Africa 2000, año V, época II, número 12 (1990): 11-13.

Morgades Besari, Trinidad. "Guinea Ecuatorial y la hispanidad," Africa 2000, año II, época II, número 1(1987): 39-41.

Ndongo-Bidyogo, Donato. Antología de la literatura guineana. Madrid: Editorial Nacional, 1984.

. Historia y tragedia de Guinea Ecuatorial. Madrid: Editorial Cambio 16, 1977.

. "Hispanidad" Africa 2000, Año III, época II, Núm. 6(1986):3

. "Literatura hispanoafricana," Mundo Negro (Enero 1998): 9.

Ngom Faye, Mbare. Diálogos con Guinea. Panorama de la literatura guineoecuatoriana de expresión castellana a través de sus protagonistas. Madrid: Labrys 54, 1996.

Ngugi Wa Thiong'o. "The Culture of Silence and Fear". South (May 1984): 37-38. 